\title{
МАРКЕТИНГ
}

УДК 339.187.4

JEL classification: M31

\author{
Афанасьєва К.O. \\ ORCID ID: 0000-0003-4790-7737 \\ Зозульов О.В. \\ канд. економ. наук, професор \\ ORCID ID: 0000-0001-7087-2080
}

Національний технічний університет Украӥни

«Київський політехнічний інститут імені Ігоря Сікорського»

\section{РОЗРОБЛЕННЯ СТРАТЕГІЇ ПРОСУВАННЯ КОМПАНІЇ У КІБЕРПРОСТОРI}

\section{DEVELOPING PROMOTIONAL STRATEGY IN CYBERSPACE}

На сьогоднішній день за рахунок розвитку науки та технологій змінюються ринкові умови для роботи підприємств. Тепер, за рахунок розповсюдження мережі Інтернет та доступності смартфонів, споживач у будь-який момент має доступ до інформації про товари, яких стає все більще, щзо призводить до перенасичення ринку. Усе иче сприяє тому, щчо економіка переходить від масового виробництва до більи індивідуального формування пропозиції, i клієнт отримує все більше впливу на виробника. Тому виникає необхідність у використанні нових інструментів маркетингу, адже ринок стає все більи конкурентним, а вимоги споживачів - більш високим. Це обумовлює особливості епохи метамодерну, вплив якої на споживачів та економічний стан компаній описаний та проаналізований у статті. Об'єктом дослідження обрано стратегію просування компанії у кіберпросторі. У даній статті визначено поняття «кіберпростір» та «мережа Інтернет», окреслені їхні складові. На основі иъього визначені особливості кіберпростору, щчо впливають на діяльність сучасних компаній. Проведений аналіз изього впливу з точки зору комунікачій, збуту та промислового ринку. Далі представлений спеціально створений загальний хід розробки стратегії просування компанії $у$ кіберпросторі у вигляді структурно-логічної схеми, яка складається з окремих блоків: характеристика компанії, стратегія збуту, вибір просторі існування компанії, спосіб присутності компанії у мережі Інтернет, стратегія комунікації. Останній блок включає в себе інструменти для просування: ATL, BTL, TTL для кіберпростору та класичні, рекомендації щодо використання ичих інструментів та законодавчі акти, які регулюють їхнє використання; блок медіа планування, медіабаїнгу, рекомендації щуодо розробки рекламного повідомлення,особливості формування бюджету для реалізації стратегії просування та показники контролю і ефективності комунікацій, які включають себе економічні та комунікачійні характеристики.

Ключові слова: метамодерн, кіберпростір, мережа Інтернет, стратегія просування, комунікації, промисловий ринок.

Today, due to the development of science and technology, market conditions for the work of enterprises are changing. Now, at the expense of the distribution of the Internet and the availability of smartphones, the consumer at any time has access to information about products 
that are becoming more, which leads to over-saturation of the market. All this contributes to the fact that the economy moves from mass production to more individual supply of supply, and the client gets more influence on the manufacturer. Therefore, there is a need to use new marketing tools, because the market is becoming more competitive, and consumer requirements - higher. This causes the features of the metamodern era, the impact of which on consumers and the economic state of the companies described and analyzed in the article. The object of the research is the strategy of promotion of the company in cyberspace. This article describes the concept of "cyber space" and "Internet network", outlining their components. On the basis of this, certain features of cyberspace affecting the activities of modern companies. An analysis of this impact from the point of view of communications, sales and the industrial market has been conducted. The following is a specially created general course of developing a strategy for promoting a company in cyberspace in the form of a structural and logical scheme, which consists of individual units: company characteristics, marketing strategy, choice of space of the company existence, the way of company presence in the Internet, communication strategy. The latest block includes promotion tools: ATL, BTL, TTL for cyberspace and classic, recommendations for using these tools and legislation governing their use; a block of media planning, media baying, recommendations for the development of advertising messages, peculiarities of budget formation for the implementation of the promotion strategy and indicators of control and efficiency of communications, which include economic and communication characteristics.

Keywords: metamodern, cyber space, Internet, promotion strategy, communications, industrial market.

Вступ. Сьогодні маркетинг і новітні технології стали основними ресурсами інтенсифікації діяльності підприємств. Використання інтерактивних засобів комунікації відіграє важливу роль для маркетингових цілей від інформування клієнта про наявність тих чи інших продуктів до здійснення продажу. Багато компаній розширюють спектр каналів розподілу послуг за рахунок комунікаційних можливостей кіберпростору, у першу чергу - глобальної мережі Інтернет.

Проблемам просування продукції присвятили дослідження такі зарубіжні та вітчизняні вчені-економісти як Рассел Дж., Лейн В., Россітер Дж. Р., Персі Л., Команор В., Вілсон Т., Еккард І., Троккмортон Дж., Странг Р., Котлер Ф., Еванс Дж., Берман Б., Діхтль Е., Хершген Г., Швальбе Х., Хруцький В.Е., Герасимчук В.Г., Манн І.Б., Яковлєв А.І., Перерва П.Г., Кретов I.I., Діброва Т.Г., Лебеденко М.С., Лебеденко С.О. та інші. В працях цих авторів розглянуто питання про роль просування в маркетингу, приведено характеристики методів і каналів просування, викладено питання планування окремих заходів просування, деталізовано прийоми, що використовуються при плануванні i реалізації заходів просування. Але недостатньо уваги приділено особливостям просування у кіберпросторі, в тому числі у мережі Інтернет.

Постановка завдання. Метою дослідження $\epsilon$ : визначити вплив особливостей кіберпростору на діяльність компаній; структурувати та впорядкувати складові розробки стратегії просування компанії у кіберпросторі, окресливши різницю між поняттями «кіберпростір» та «нтернет». 
Методологія. Для визначення шляхів та способів вирішення поставлених завдань було використано загальнонаукові та специфічні методи дослідження: діалектичний метод пізнання економічних явищ - для визначення особливостей маркетингової діяльності у кіберсередовищі; монографічний - для вивчення літературних джерел; методи системного аналізу, порівняння та морфологічного аналізу - для удосконалення термінології понятійного апарату кіберпростору та просування; методи логічного узагальнення, структурно-генетичного аналізу та синтезу - для удосконалення науково-методичних засад стратегії просування у кіберпросторі.

Результати дослідження. На сьогоднішній день людство увійшло у епоху метамодерну. Метамодерн - одна зі спроб визначити актуальну культурну реальність. Термін був запропонований в 2010 році двома голландськими філософами-теоретиками Тімотеус Вермюленом і Робіном ван ден Аккера. Свої основні ідеї Вермюлен і Аккер виклали у праці «Нотатки про метамодернізм». Але перед тим, як визначити, що таке метамодерн, з'ясуємо, чим характеризуються попередні епохи. Результати представлені у таблиці 1.

Кіберпростір характеризується трьома основними ознаками: - це інформаційний простір; - він $є$ комунікативним середовищем; - він утворюється за допомогою технічних систем. Таким чином для того, щоб використовувати поняття «кіберпростір» при розгляді маркетингової діяльності компанії в контексті даної роботи, виникає необхідність у формалізації поняття 3 економічної точки зору. Отже, кіберпростір - це інформаційне середовище, існування якого забезпечується цифровими технологіями, що утворюють специфічну сферу діяльності, яка включає в себе систему економічних відносин, направлену на створення цінностей та реалізацію економічних інтересів. Таким чином, можна сказати, що кіберпростір значною мірою впливає на здійснення комерційної діяльності компаній, змінює підходи до ведення бізнесу і має істотний вплив та загальну маркетингову парадигму в умовах метамодерну.

Найбільші зміни відбуваються у сферах комунікацій та збуту, і це має своє відображення на діяльності промислового ринку. Результати аналізу змін, спричинених розвитком кіберсередовища, представлені у таблиці 2. 
Таблиця 1 - Порівняння епох модерну, постмодерну та метамодерну

\begin{tabular}{|c|c|c|}
\hline Епоха & $\begin{array}{c}\text { Економічні задачі та інструменти } \\
\text { реалізації }\end{array}$ & $\begin{array}{c}\text { Соціальні задачі ті інструменти } \\
\text { реалізації }\end{array}$ \\
\hline Модерн & $\begin{array}{l}\text { - Індустріалізація; } \\
\text { - Перехід до } 3 \text { та } 4 \text { технологічних } \\
\text { укладів, розвиток атомної енергії, } \\
\text { електроніки, хімічної } \\
\text { промисловості, квантової фізики, } \\
\text { тощо; } \\
\text { - Концепція орієнтації на продажі; } \\
\text { - Виробничо-орієнтована концепції } \\
\text { діяльності; } \\
\text { - «Детройтська» модель організації } \\
\text { бізнесу. }\end{array}$ & $\begin{array}{l}\text { - Уніфікація та імперативність } \\
\text { людської поведінки; } \\
\text { - Відмова від релігії, на першому } \\
\text { місті - матеріальне, духовне - } \\
\text { вторинне; } \\
\text { - Прагнення створити універсальну, } \\
\text { «массову» людину, що існує в чітко } \\
\text { визначених рамках. }\end{array}$ \\
\hline Постмодерн & $\begin{array}{l}\text { - Постіндустріалізація; } \\
\text { - Продукто-орієнтована концепція; } \\
\text { - Перехід до концепції маркетингу; } \\
\text { - Удосконалення виробничих } \\
\text { процесів, підвищення } \\
\text { інноваційності; } \\
\text { - Перехід до «голлівудської» моделі } \\
\text { організації бізнесу. }\end{array}$ & $\begin{array}{l}\text { - Плюралізм; } \\
\text { - Мультикультуралізм; } \\
\text { - Варіативність моди; } \\
\text { - Демократизація поведінки у } \\
\text { суспільстві. }\end{array}$ \\
\hline $\begin{array}{l}\text { Метамодерн } \\
\text { (пост- } \\
\text { постмодерн) }\end{array}$ & $\begin{array}{l}\text { - Інформаційне суспільство; } \\
\text { - Розповсюдження реінженірингу } \\
\text { бізнес-процесів; } \\
\text { - Виробництво орієнтоване на } \\
\text { індивідуального клієнта; } \\
\text { - Гнучка структура управління } \\
\text { підприємством, реорганізації; } \\
\text { - Інформаційні технології, } \\
\text { автоматизовані системи управління; } \\
\text { - Імітаційне моделювання бізнес- } \\
\text { процесів; } \\
\text { - Розвиток «віртуальних } \\
\text { підприємств»; } \\
\text { - Багаторівневі дружні інтерфейси; } \\
\text { - підходи ЕRР (Еnterрrise resourсе } \\
\text { рlаппіng); } \\
\text { - Цифрова економіка, } \\
\text { діджиталізація; } \\
\text { - Споживчий ІоТ та Індустрія 4.0. }\end{array}$ & $\begin{array}{l}\text { - Зростання ролі кожної особистості } \\
\text { у суспільстві; } \\
\text { - Вихід за рамки: світ і культура - } \\
\text { один загальний потік змістів, які є } \\
\text { частиною загальної істини, де } \\
\text { кожна } \\
\text { одиниця важлива і самодостатня; } \\
\text { - Політика - більш особиста та } \\
\text { менш елітарна; } \\
\text { - Багатовимірність мистецтва; } \\
\text { - Просьюмеризм; } \\
\text { - Крауд-технології; }\end{array}$ \\
\hline
\end{tabular}




\section{Таблиця 2 - Результати впливу кіберпростору на діяльність компаній}

\begin{tabular}{|c|c|}
\hline Напрямок & Результати впливу \\
\hline Комунікації & $\begin{array}{l}\text { - нові схеми комунікацій та комунікаційні моделі; } \\
\text { - зниження вартості здійснення комунікацій; } \\
\text { - збільшення охоплення аудиторії: відсутність впливу географічних } \\
\text { кордонів та обмежень у часі й тривалості здійснення комунікацій; } \\
\text { - швидкість обміну інформацією, інтерактивність та зворотній зв'язок; } \\
\text { - можливість здійснення максимальної персоніфікації; } \\
\text { - постійний зв'язок зі споживачем (відстеження за допомогою модулів та } \\
\text { CRМ-систем) - нові інструменти впливу та управління поведінкою; }\end{array}$ \\
\hline Збут & $\begin{array}{l}\text { Містить дві складові: } \\
\text { 1. Передача прав власності: } \\
\text { - хмарні технології для електронного документообігу - аутсорсинг цієї } \\
\text { функції посереднику, що працює за логікою замовника та гарантує } \\
\text { здійснення транзакцій; } \\
\text { - створення правової основи для функціонування електронної комерції; } \\
\text { - електронні контракти } \\
\text { - електронні розрахунки (платіжні картки, цифрова готівка, крипто валюти } \\
\text { тощо) } \\
\text { - електронна ідентифікація (цифровий підпис, одноразовий ідентифікатор, } \\
\text { печатка тощо) } \\
\text { - спеціальні системи захисту інформації (на базі блокчейн тощо) } \\
\text { 2. Товарорух: } \\
\text { - активний розвиток логістичної інфраструктури; } \\
\text { - збільшення навантаження на логістину систему через підвищення } \\
\text { кількості замовлень через інтернет (у тому числі доставки з інших країн), } \\
\text { особливо у дні розпродажів; } \\
\text { - нові формати доставки: поштомати у банках, торговельних центрах; } \\
\text { швидка доставка на мотоциклах у межах міста; доставка на дронах тощо. }\end{array}$ \\
\hline \multicolumn{2}{|c|}{ Промисловий ринок } \\
\hline \multicolumn{2}{|c|}{$\begin{array}{l}\text { - Датчики, що постійно аналізують рівень зносу запчастин та компонентів на виробництві -> } \\
\text { предикативне профілактичне обслуговування (попередження поламок, швидка реакція та } \\
\text { розповсюдження інформації); } \\
\text { - Оперативне та точне прогнозування, засноване на поточних даних, що оперативно } \\
\text { оновлюються -> автоматичне формування та відправлення торгової пропозиції у спеціально } \\
\text { визначений час, коли потреба актуалізована. }\end{array}$} \\
\hline \multicolumn{2}{|c|}{$\begin{array}{l}\text { - Мінімізація людського втручання та помилок, спричинених людським фактором -> } \\
\text { раціональні та вимірювальні критерії вибору продукції; здійснення покупки з мінімальним } \\
\text { людським втручанням; автоматизований контроль якості; } \\
\text { - Автоматизація і роботизація бізнес-процесів: від виробництва, закупівель та } \\
\text { документообігу до здійснення розрахунків та комунікацій; } \\
\text { - Хмарні системи для збору та зберігання інформації - зменшення витрат на підтримання } \\
\text { пропускної здатності систем зв’язку та збереження інформації; } \\
\text { - Сповільнення старіння обладнання і систем промислової автоматизації за рахунок } \\
\text { оперативного оновлення обладнання через ІоТ-додатків; } \\
\text { - Оптимізація автоматизованого виробництва -> зменшення витрат на оплату праці, } \\
\text { логістику, економія часу тощо; }\end{array}$} \\
\hline
\end{tabular}




\title{
Продовження таблиці 2
}

\begin{abstract}
- Відслідковування якості продукції навіть після здійснення продажу (вбудовані датчики) - Відмова від профілактичного огляду на календарній основі на користь предиктивної підтримки (точне передбачення подій у життєвому циклі товару за рахунок історичних даних; визначення моделей подій, які передують поламкам)

-> підтримання якості продукції на належному рівні, продовження життєвого циклу товару, уникнення простоїв виробництва -> можливість збільшення доходів від забезпечення безвідмовної роботи з преміальним ціноутворенням за контрактами сервісного обслуговування SLA (Service Level Agreement);

- Визначення вимог до продукту від споживачів за допомогою датчиків -> покращення промислового дизайну та ергономічності продуктів.

- Збільшення лояльності через управління гарантіями ( за рахунок підтримки зворотного зв'язку через датчики) -> додатковий дохід від сервісу, можливість уникнули шахрайських звинувачень;

- Покращення систем безпеки на виробництві за рахунок автоматизації слідкування за процесами та систем М2М комунікацій;

- Динамічне планування логістичних маршрутів (відстеження через GPS, безпілотні автомобілі - оптимізація маршрутів та пришвидшення доставки);

- Скорочення внутрішніх витрат (автоматична перевірка та економія електроенергії;

- Розповсюдження PaaS-моделей.
\end{abstract}

Кожен з розглянутих аспектів має свій вплив на характер економічних взаємовідносин у кіберпросторі, i, як наслідок, певним чином формує особливості маркетингової діяльності компанії.

Основною ціллю стратегії просування $є$ забезпечення споживачів повноцінною інформацією для прийняття рішення про покупку конкретного товару. Для цього необхідно визначити, яку саме інформацію необхідно надати споживачам, які методи та інструменти необхідно використати для цього, в який момент необхідно надати цю інформацію, через які канали. Для цього компанії досліджують споживачів і формують модель прийняття рішення про покупку.

В найбільш широкому розумінні, просування (англ. «promotion») - це будь-яка форма комунікацій, що використовується для інформування, нагадування, стимулювання збуту, формування позитивного ставлення та іміджу серед існуючих та потенційних споживачів. Здійснення просування у кіберпросторі має свої відмінні риси. На цьому етапі необхідно зауважити, що в даній роботі кіберпростір розглядається як інформаційне середовище, існування якого забезпечується цифровими технологіями, що утворюють специфічну сферу діяльності, яка включає в себе систему економічних відносин, направлену на створення цінностей та реалізацію економічних інтересів. А мережа «Інтернет» в даному випадку - це матеріальне відображення кіберпростору в реальному світі: це не сам «кіберпростір», а технічна умова, за якої він може існувати [2]. Тому для більшої наочності та практичної значущості результатів у подальшому дослідженні 
розглядатимемо маркетингову діяльність компанії у матеріальному відображенні кіберпростору - мережі Інтернет.

Для того щоб структурувати процес створення стратегії просування у мережі Інтернет, визначимо загальний хід розробки стратегії у вигляді схеми, зображеної на рисунку1.

Блок 1. Компанія . Розробка будь-якої стратегії обов'язково базується на цілях компанії. Наступним кроком $є$ визначення та формалізація маркетингових цілей (в основному, вони направлені на здійснення впливу на свідомість споживачів, збільшення частки ринку компанії або вихід на нові ринки).

Після цього аналізується продукт, ринок та споживачі. Продукт: які він має характеристики, чи потребує роз'яснення та демонстрації - звідки визначається, потрібні статичні або динамічні рекламні інструменти. Ринок: ставлення до реклами, іiі сприйняття, законодавство. Споживачі: проводиться сегментування, позиціонування. Наступним кроком визначається цільова аудиторія для здійснення комунікацій, яка не завжди може співпадати 3 сегментами; це фізичні особи, на яких буде спрямований комунікаційний вплив; один сегмент, наприклад, може складатися 3 кількох цільових аудиторій.

Далі визначаються цілі комунікацій для кожної цільової аудиторії. Як правило вони спрямовані на стимулювання цільової аудиторіях до здійснення певних дій або на зміну їхнього сприйняття товарів/компанії через зміну образу у свідомості. Цілі обов'язково повинні бути досяжними та оцифрованими, тобто мати конкретні показники.

Блок 2. Стратегія збуту. У кіберпросторі стратегія просування базується на обраній стратегії збуту i визначених для неї каналах та інструментах комунікації. Тому визначення типу старегії просування $є$ дуже важливим кроком:

- Одноканальна - використовується єдиний спосіб досягнення клієнтів. Перевагою $є$ зниження витрат та повний контроль.

- Мультиканальна - використовують декілька каналів збуту, які є слабо інтегрованими між собою і конкурують за вибір споживача

- Крос-канальна - використовують декілька каналів збуту, які вже не конкурують, а є взаємодоповнюючими.

- Омніканальна - концепція схожа з крос-канальним збутом, за винятком того, що канали використовуються одночасно [3].

- Комерційна релевантність - головна ідея: подання релевантної інформації на кожному каналі та для всіх учасників відносин [4]. 


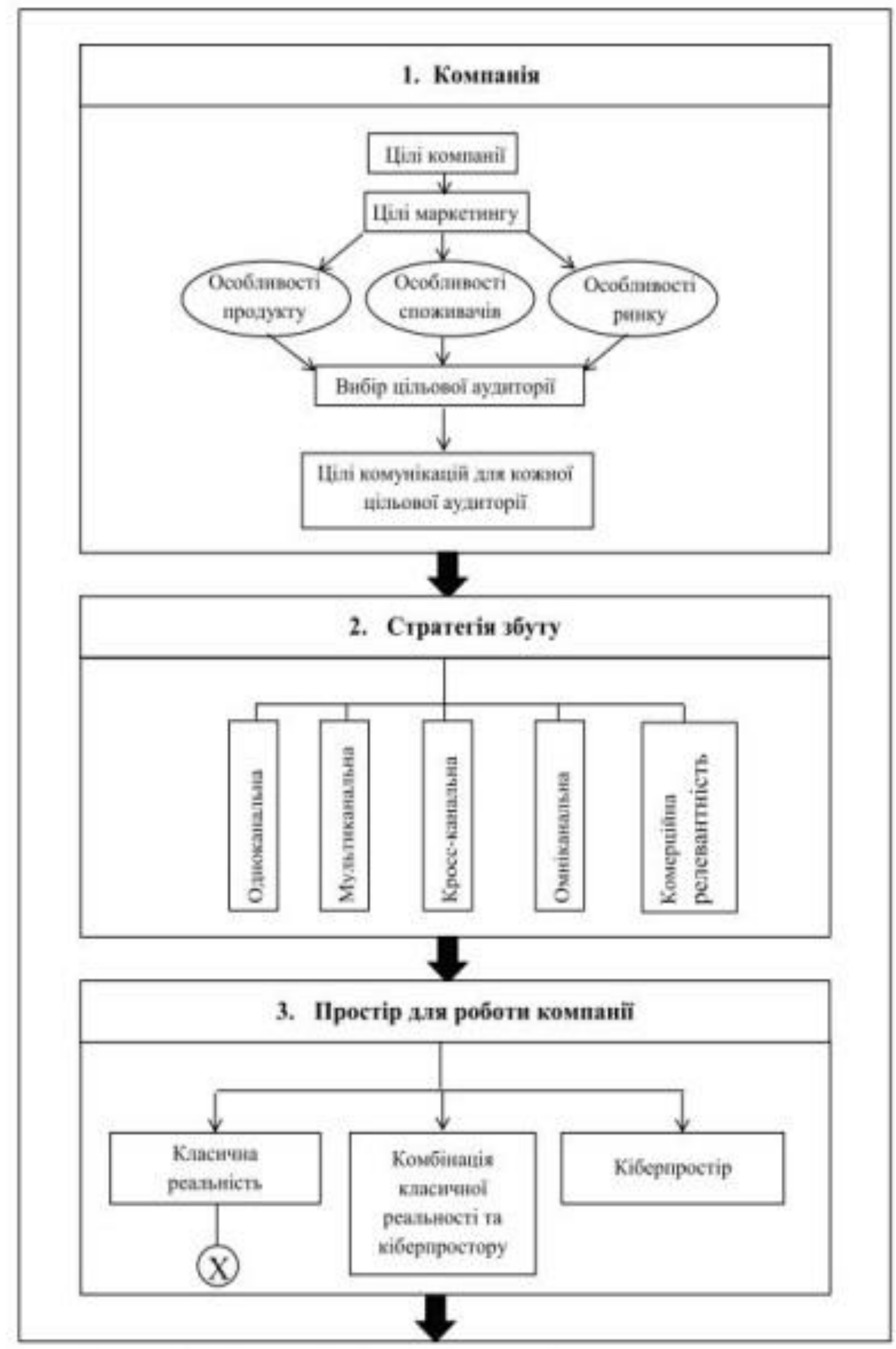

Рисунок 1 - Загальний хід розробки стралегії просування компанії у мережі Інтернет 


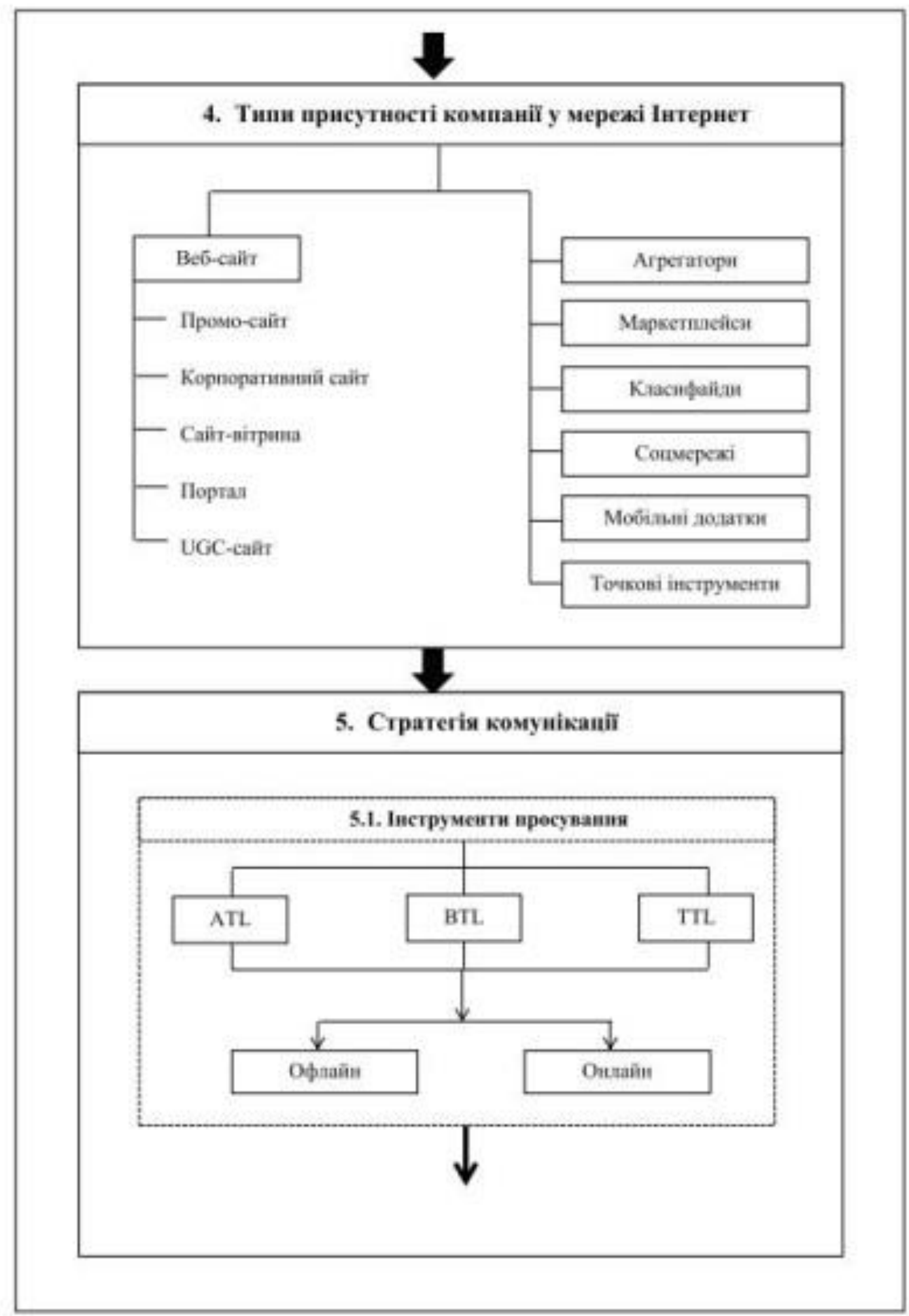

Рисунок 1 - Загальний хід розробки стратетій просування компанії у мережі Іитернет, продовкени 


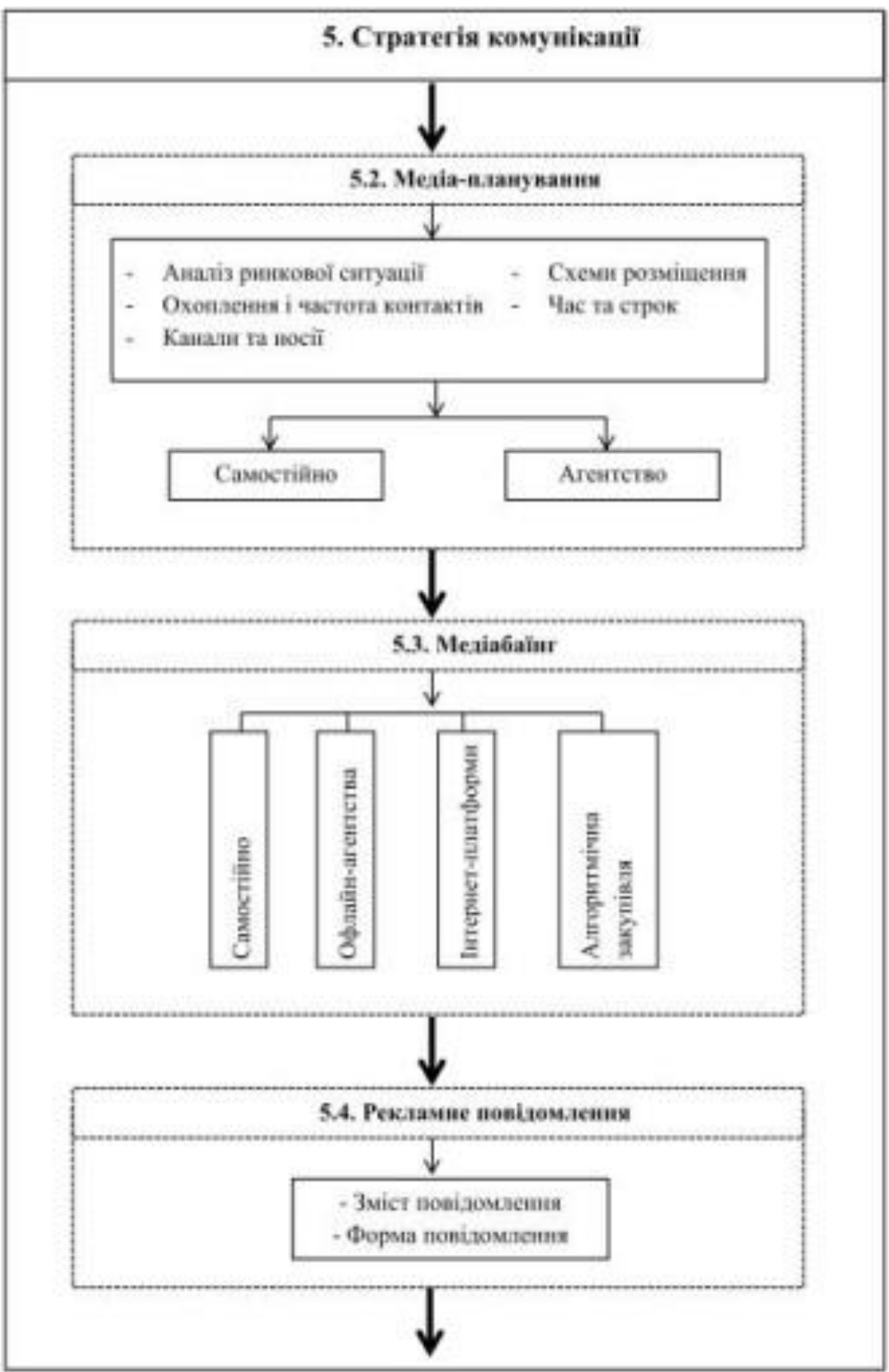

Рисунок 1 - Загальний хід розробки стратегії просування компанії у мережі Іитериет, продовжения 


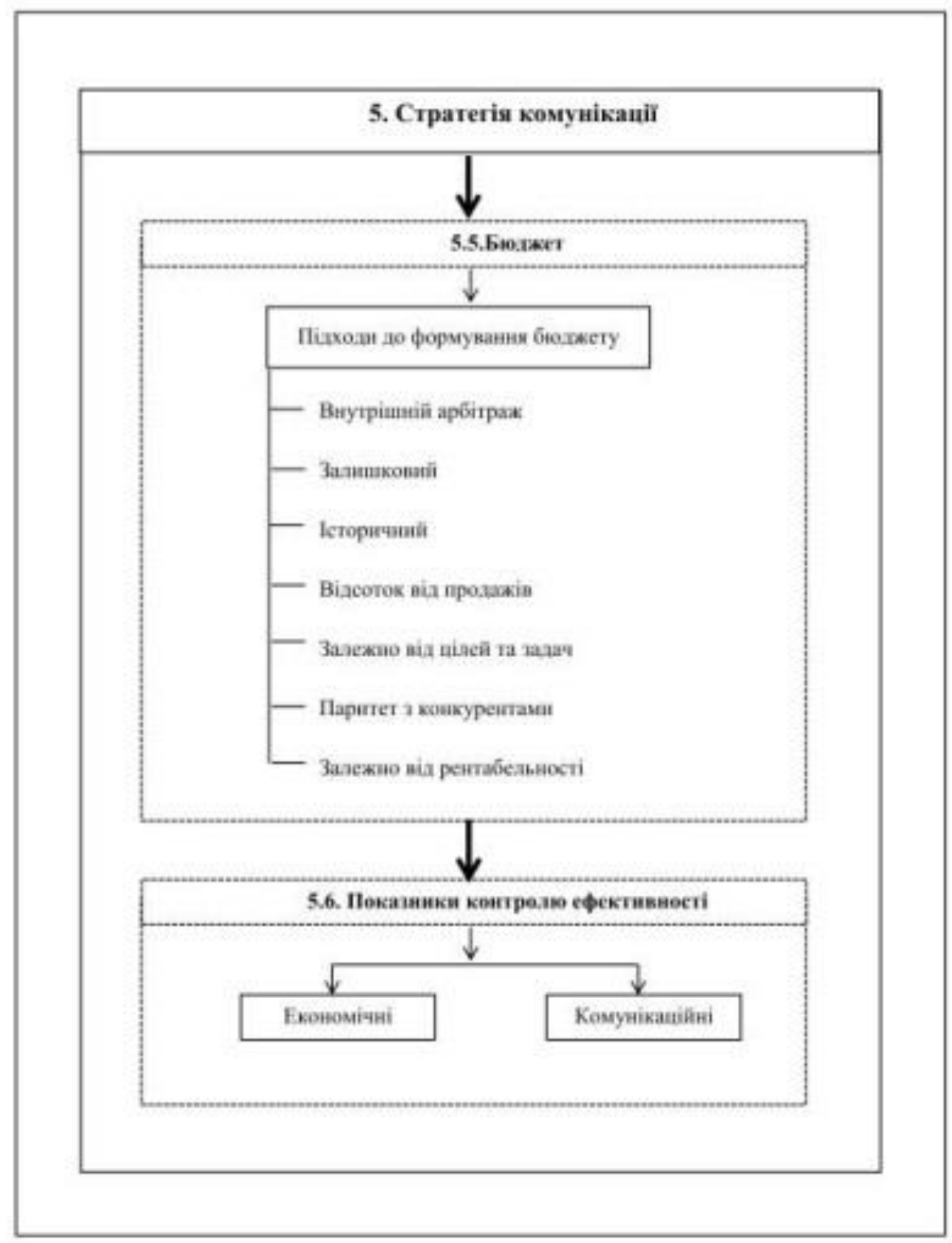

Рисунок 1 - Загальний хід розробки стратегії просування компанії у мережі Іитернет, продовжеиня 
Блок 3. Простір для роботи компанії. Наступним кроком необхідно визначити простір, в якому працюватиме компанія: класична реальність (фізичний світ), кіберпростір (цифровий світ) або обидва простори. Якщо компанія обрала останній варіант - потрібно визначити ступінь співвідношення фізичного представництва та цифрового, особливості їхньої взаємодії. Надалі будемо розглядати варіанти, коли компанія обрала кіберпростір або змішаний.

Блок 4. Варіанти присутності компанії у мережі Інтернет. Якщо компанія на попередньому кроці обрала кіберпростір або змішаний, тепер необхідно визначити спосіб присутності компанії у інтернеті як фізичному відображенні кіберпростору. Це може бути сайт одного з нижченаведених типів:

1. Сайт-візитівка (лендінг, промо-сайт) - це мінімально необхідний, але достатній набір інформації, поширення якої корисно як для компанійпочатківців, так і для давно працюючих організацій. Це своєрідна візитна картка фірми, яка містить основну інформацію про діяльність компанії і іiі контактні дані.

2. Корпоративний сайт - цей сайт є більш серйозною структурною одиницею. Сайти такого типу виступають в ролі інструменту, що допомагає залучати нових клієнтів і партнерів для співпраці, розширюють ринок збуту компанії, підвищуючи рейтинг і довіру в своїй сфері бізнесу. Даний сайт може служити рекламним майданчиком в інтернеті, тут можна публікувати свою продукцію або послуги з можливістю оформити замовлення прямо на сайті.

3. Сайт-вітрина (каталог) - це логічно організований, структурований каталог, головне призначення якого - залучення клієнтів. Розміщуючи детальну інформацію про товар, або групи товарів на сторінках сайту вітрини ви отримуєте відмінний інструмент для реклами і поширення інформації про компанію в інтернеті.

4. Інтернет-магазин - це сайт-вітрина, де клієнт може не тільки переглянути товари на сторінках каталогу, але і купити їх. Там можна "покласти" в "кошик" товари і оформити покупку тут же, вибрати зручний спосіб оплати і доставки товару. Повний аналог звичайного магазину тільки в інтернеті. Головні якості даного сайту - зручність і функціональність. Користувачі повинні мати можливість легко знайти необхідний товар, відправити його в "кошик" і оформити покупку в кілька кліків.

5. Портал - це тип сайту, який має свою індивідуальність і певну тематику. Структура i набір функціональних модулів сайту-порталу влаштовані таким чином, щоб відвідувачі сайту могли максимально в повному обсязі отримувати інформацію. Як правило, на сайті-порталі завжди є стрічки новин і подій, форуми, де можна обговорити певні теми, висловити свою думку. 
6. UGC-сайт - сайт, на якому контент створюється за участю відвідувачів, з англ. UGC - user generated content. Нариклад: форуми, соцмережі, маркетплейси, дошки оголошень тощо)

Якщо компанія не має можливості розробити власний сайт, або це не входить у iii плани, можна обрати інший шлях присутності у мережі Інтернет: розмістити окремі товари на сайтах-агрегаторах (hotline.ua, price.ua, ek.ua, m.uа тощо) або створити сторінку компанії та додати туди товари на маркетплейсах (bigl.ua, prom.ua), розмістити інформацію про товари на класифайдах - сайтах з рубрикованою рекламою (olx, besplatka.ua, тощо), створити власну сторінку у соцмережах (youtube, Facebook, Instagram тощо), розробити власний мобільний додаток або лише точково використовувати окремі інструменти інтернет-маркетингу (публікації в онлайн-3MI, emailрозсилки тощо).

Для того, щоб обрати вірний спосіб представлення компанії у мережі Інтернет необхідно проаналізувати можливості компанії а наступними критеріями, що наведені на рис. 2.

Блок 5.Стратегія комунікаиії. На даному етапі починається безпосередньо розробка комунікаційної стратегії в рамках стратегії просування.

Блок 5.1.Інструменти просування. Засновуючись на попередніх рішеннях компанія обирає інструменти для просування. Якщо вона працює і у кіберпросторі, і у класичній реальності, для кожного з напрямків необхідно обрати відповідні інструменти та розробити систему їхнього взаємоузгодженого використання для досягнення ефекту синергії.

Загалом інструменти просування можна розподілити на наступні групи: 1) ATL (від англ. «above-the-line») - різноманітні типи реклами у традиційних 3МI: телебачення, радіо, поліграфія, реклама «out-of-home» зовнішня та внутрішня. Це масові, неособисті, розраховані на широку аудиторію платні інструменти, які експресивно впливають на емоції споживачів та, за законом, розповсюджуються від імені відомого спонсора.

2) BTL ( від англ. «below-the-line») - PR (від англ. «public relations», як правило, неособистий безоплатний інструмент, основна ціль якого формування позитивного іміджу), стимулювання збуту (короткострокові заходи для залучення споживачів та спонукання їх до дії; часто використовуються для завантаження/розвантаження роздрібної торгівлі; підвищують лояльність, як правило, тільки в купі з іншими інструментами маркетингу), особисті продажі (єдиний інструмент комунікацій, що одразу призводить до здійснення покупки, характеризується особистим контактом продавця і покупця), івент-маркетинг, участь у виставках, спонсорство, промо-акції, управління базами даних, партизанський та вірусний маркетинг тощо.

3) TTL (від англ. «through-the-line») - інтегровані маркетингові комунікації, поєднання інструментів ATL та BTL через поступове розмиття чіткої границі між ними. 


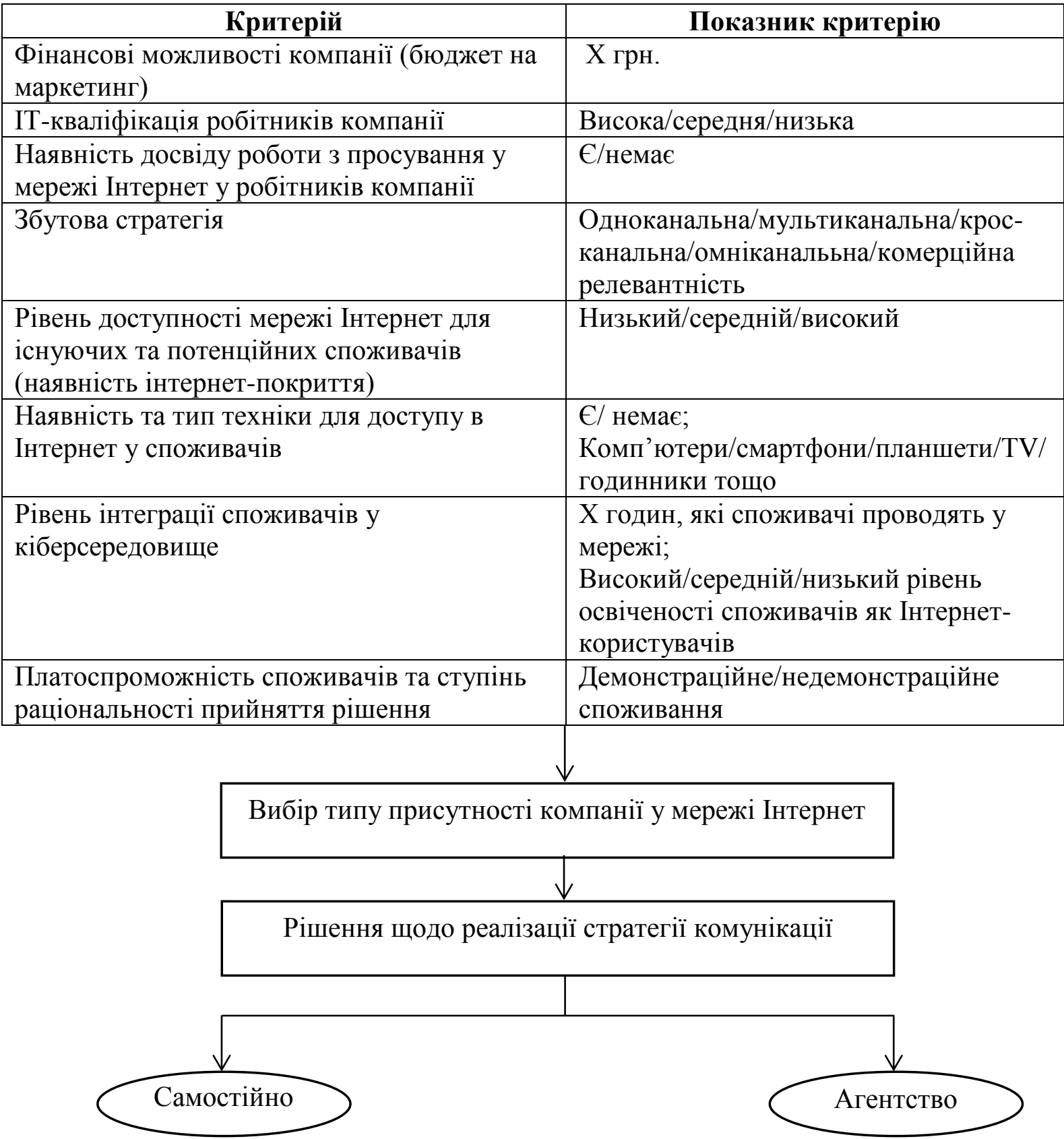

Рисунок 2 - К Критерії для вибору типу присутності компанії у мережі Інтернет Джерело: розробка авторів

Інтегровані маркетингові комунікації - сукупність інструментів просування, що повністю реалізують комунікаційні завдання компанії та дозволяють отримати сукупний кумулятивний ефект та ефект синергії від їх поєднання.

Отже, основними інструментами маркетингових комунікацій у кіберпросторі $\epsilon$ реклама, стимулювання збуту, формування громадської думки, брендинг.Реклама реалізується на Web-сайтах (в тому числі і самої 
компанії) у вигляді банерної, текстової та мультимедійної реклами, реєстрації сайту в каталогах, індексації сайту пошуковими системами, за допомогою електронної пошти, списків розсилки, оголошень на конференціях і на дошках оголошень. Стимулювання збуту здійснюється під час проведення конкурсів, ігор, розіграшів, лотерей; за допомогою премій, призів, подарунків, пробних зразків і демонстраційних версій; при наданні знижок і купонів. Зв'язки з громадськістю виражаються в публікації матеріалів на webсайті компанії, публікації матеріалів і новин в ЗMI Інтернету, на спеціалізованих і тематичних сайтах, проведенні маркетингових заходів з їх освітленням в Інтернеті, участі в конференціях, спонсорстві [5].

У кіберпросторі існує велика кількість інструментів, які дозволяють зібрати інформацію про споживачів у Інтернеті. Тому для моніторингу поведінки споживачів в Інтернеті існують спеціальні програми. Наприклад: BlackBoxPro от Asm Software, LanAgent от NetworkProfi и StaffCop от AtomPark Software тощо. Але компаніям необхідно отримувати інформацію про те, як споживаі ставляться до певних подій та явищ, для цього необхідно швидко аналізувати інформаційний простір в інтернеті. Для цього існує велика кількість програм, наприклад: YouScan, Google Alerts, SocialMention, Marketing Grader, Competitive Research \& Keyword Research тощо. Аналогічні сервіси можна використовувати для відслідковування і аналізу діяльності конкурентів.

Разові рекламні кампанії і зусилля відділу продажів або продавців консультантів 3 появою інтернету перестали бути визначальними при ухваленні рішень про покупку продуктів і послуг як в В2В, так і в В2С. Зусилля цілого відділу продажів будуть марні, якщо немає лідів з якими можна було б працювати. Тому в умовах, що склалися, набула розвитку автоматизація маркетингу. Це цілий комплекс послуг, який не тільки допомагає дізнатися всі дані про потенційного покупця, а й утримати його, стимулювавши на здійснення покупки. Впровадження систем автоматизації маркетингу дозволило створити унікальні персоналізовані кампанії складаються з одного або декількох процесів, здатні самостійно запускатися при виконанні тієї або іншої дії (тригера) покупця.

Необхідно враховувати, що компанії, які збирають дані про споживачів, сьогодні, обов'язково повинні дотримуватися політики конфіденційності. Наприклад, у зв'язку з активізацією кіберзлочинності та викраданням особистої інформації людей $з$ соціальних мереж, банків та інших установ, що мають власні бази даних з інформацією про своїх споживачів, у травні 2018 року був прийнятий Загальний регламент щодо захисту даних (оновлений Регламент СС 2016/679 від 27 квітня 2016 року або GDPR - General Data Protection Regulation). Новий регламент надає резидентам $€ C$ інструменти для повного контролю над своїми персональними даними. GDPR має екстериторіальне дію і застосовується до всіх компаній, які обробляють персональні дані резидентів і громадян $\mathrm{CC}$, незалежно від місцезнаходження такої компанії. 3 травня 2018 року 
посилюється відповідальність за порушення правил обробки персональних даних: за GDPR штрафи сягають 20 мільйонів євро (близько 1,5 млрд руб.) Або 4\% річного глобального доходу компанії. Персональні дані за GDPR - це будь-яка інформація, що відноситься до ідентифікованого або ідентифікованому фізичній особі (суб'єкт даних), по якій прямо або побічно можна його визначити. До такої інформації належить в тому числі ім'я, дані про місце розташування, онлайн-ідентифікатор, один або декілька факторів характерних для фізичної, фізіологічної, генетичної, розумової, економічної, культурної або соціальної ідентичності цієї фізичної особи (п. 1 ст. 4). Визначення широке і досить чітко дає зрозуміти, що навіть IP адреси також можуть бути персональними даними. Важливо відзначити, що існують певні типи персональних даних, що відносяться до категорії особливих або конфіденційних персональних даних. Це інформація, яка розкриває: расове або етнічне походження, політичні погляди, релігійні або філософські переконання і членство в профспілках. Крім того, до цієї групи належать генетичні, біометричні дані, які використовуються для ідентифікації фізичної особи, дані про стан здоров'я, відомості, що стосуються сексуального життя або сексуальної орієнтації (ст. 9) [5].

На території нашої держави діє Закон України "Про захист персональних даних", що регулює відносини, пов'язані із захистом персональних даних при їх обробці.

Блок 5.2. Медіапланування. На цьому етапі відбувається дослідження каналів просування (оцінюються результати медійних панелей, плануються кампанії комунікацій, визначається широта охоплення аудиторії, частота контактів з нею, визначаються канали комунікацій та носії, розробляються схеми розміщення реклами, визначається час та довготривалість проведення рекламних кампаній. Цю діяльність компанія може проводити самостійно або за допомогою агентства.

Блок 5.3. Медіабаӥнг. На цьому етапі обираються канали для розміщення реклами. При необхідності здійснюється купівля прав на розміщення реклами у цих каналх. Виділяють наступні типи каналів:

- $\quad$ Платні - дозволяють залучити споживачів за рахунок інвестицій у відвідування або конверсію. Аналоги традиційних медіа. Наприклад: платний пошук, цифрові вивіски, контекстна реклама тощо.

- Власні - належать компанії або бренду. Сайти, блоги, сторінки в соціальних мережах, списки е-таil розсилки, мобільні додатки.

- Напрацьовані - генеруються шляхом нетворкінгу та PR впливу на цільові групи для збільшення обізнаності про бренд. Social media marketing (SMM), вірусний маркетинг, лідери думок і адвокати споживачів, незалежні блогери, «сарафанне радіо», флешмоби, хештеги.

Медіабіїнг можна здійснювати самостійно закуповуючи місця для розміщення реклами, можна звернутися до агентств, здійснити покупку за 
допомогою баїнгових-платформ у мережі Інтернет або використати механізм алгоритмічної закупівлі реклами (programmatic advertising buying).

Блок 5.4. Рекламне повідомлення. Далі необхідно розробити рекламне повідомлення, найкраще, якщо це зробить безпосередньо сама компанія. В першу чергу необхідно визначити, яке основне повідомлення буде міститися у даній кампанії просування (дати відповідь на питання: що говоримо?), далі - розробити креативну форму надання цієї інформації (дати відповідь на питання: як говоримо?). Для розробки креативу при необхідності можна звернутися до копірайтерів.

Блок 5.5. Бюджет. При формуванні бюджету необхідно враховувати вартість закупівлі медіаносіїв, проаналізувати рейтинги GRP (сукупний рейтинг за усіма рекламними носіями) та TRP (цільовий рейтинг лише серед цільової аудиторії), оцінити витрати на виробництво рекламної продукції (вартість дизайну банерів, анімації, спеціальних текстових форматів, відео, поліграфії тощо), врахувати витрати на комісійні агентству, транспорт та логістику (особливо для офлайн-каналів).

Далі необхідно обрати один з підходів до формування бюджету:

- На основі внутрішнього арбітражу (розв'язок дискусійних питань за рахунок висловлення особистої думки власника компанії).

- Залишковий метод (змінний бюджет, який формується 3 залишку бюджетів від інших кампаній).

- Історичний (метод, що сформувався у компанії на основі традиційних моделей поведінки у подібних ситуаціях).

- Відсоток від очікуваних продажів/ прибутку (використовується при умові, що стратегія конкурентів не змінилась, та обсяги продажів можна передбачити. Негативною рисою $є$ те, що реалізація товарів у даному випадку виступає причиною, а просування - наслідком).

- В залежності від цілей та завдань.

- На основі паритету з конкурентами (для утримання існуючої долі ринку).

- На основі рентабельності витрат (реклама у даному випадку $є$ інвестиціями у майбутнє, за допомогою розрахунків визначається необхідний обсяг продажів для покриття рекламних витрат).

Блок 5.6. Розробляються показники для контролю ефективності комунікацій.

Показники повинні відображати економічну ефективність (щоб можна було дослідити співвідношення «витрати-прибуток») та комунікаційну ефективність (який вплив відбувся на споживача). Для кожної компанії дані показники будуть визначатися індивідуально та характеризуватимуть ступінь досягнення маркетингових цілей.

Висновки. Наукова новизна роботи полягає в удосконаленні методології формування стратегії просування товарі компанії в частині розроблення структурно-логічної схеми просування компанії у кіберпросторі на промисловому ринку. Подальшого розвитку набули теоретичні положення 
маркетингу у кіберпросторі в частині систематизації складових кіберпростору та уточнення особливостей впливу кіберпростору на діяльність компаній.

Отримані результати можуть використовуватися компаніями, що працюють на промисловому ринку та займаються плануванням власної маркетингової комунікаційної політик в кіберпросторі.

\section{Література:}

1. Метамодерн - новый способ смотреть на мир [Електронний ресурс]. - 2018. URL: https://newtonew.com/culture/wow-metamodern.

2. Экономические преступления, совершаемые в киберпространстве, и меры противодействия им [Електронний ресурс] http://law.edu.ru/book/book.asp?bookID=1656557

3. Multi-channel, Cross-channel, Omnichannel: What difference? [Електронний ресурс] // Marketing \& Growth Hacking Publication. - 2016. - Режим доступу: https://blog.markgrowth.com/multichannel-cross-channel-omni-channel-whatis-thedifference-3fc9f84c84b5

4. Ben Rund Commerce Relevancy - The Next Generation of Omnichannel Commerce [Електронний ресурс]. - URL: https://blogs.informatica.com/2015/10/14/commercerelevancythe-next-generation-of-omnichannelcommerce/\#fbid=u8Bjwkg0Reo

5. Коммуникационные модели среды Интернет [Електронний ресурс] - URL: https://studopedia.su/13_105635_kommunikatsionnie-modeli-sredi-internet.html

6. General Data Protection Regulation [Електронний ресурс] - URL: https://gdpr-info.eu/

7. Домашева Є.А., Зозульов О.В. Визначення стратегії збуту в кіберсередовищі на промисловому ринку. / Економічний вісник НТУУ «КПІ». - 2018. URL: http://ev.fmm.kpi.ua/article/view/132530/128994

УДК 339.138

JEL classification: M31

Кубишина Н. С. канд. економ. наук, дочент ORCID ID: 0000-0002-0563-1421

Національний технічний університет Украӥни «Київький політехнічний інститут імені Ігоря Сікорського»

\section{УПРАВЛІННЯ АСОРТИМЕНТНОЮ ПОЛІТИКОЮ ПІДПРИЕМСТВА MANAGEMENT OF ASSORTMENT POLICY OF THE ENTERPRISES}

У статті розглянуто підходи вітчизняних авторів до процесу управління асортиментною політикою. Виокремлено основні переваги та недоліки підходів. Різноманіття факторів, щуо впливають на процес управління асортиментною політики на різних ринках зумовлює складність виведення універсальних рекомендацій, щчо були б однаково ефективним в різних галузях. Тому постає необхідність розроблення проиесу управління асортиментною політикою, щуо давав би змогу, иляхом виконання конкретних дій, досягати високих показників ефективності. Запропоновано прочес управління асортиментною політикою, який грунтується на важливості послідовного виконання етапів та необхідності постійного контролю за зворотнім зв'язком - ефективністю асортиментної політики. Впроваджувати даний процес рекомендовано для підприємства 